\title{
Reserвсн Aвтіск: Paddy growers' technical knowledge on integrated pest management practices in Upper Brahmaputra Valley Zone of Assam
}

\author{
Article Chronicle: \\ Received : \\ 12.04.2020; \\ Revised: \\ 15.06.2020; \\ Accepted : \\ 16.07.2020
}

Key Words : Integrated pest management (IPM), Knowledge level, Paddy growers, Pesticides

Author for correspondence :

\section{P. Sharma}

R.G.V.N., Guwahati

(Assam) India

Email: patrika.sharma@ gmail.com

See end of the article for authors' affiliations

\section{P. Sharma and P. Mishra}

SUMMARY : The importance of integrated pest management (IPM) lies with the fact that, dependency for increasing agricultural production by heavy application of pesticides and chemical fertilizers has negative impact on human health as well as on the natural resource base. IPM is a concept that integrates all cultural, mechanical, biological and chemical practices of crop production which control prevent and eradicate pest population in field and makes the pest management practice a stronger approach rather than sole application of chemical pesticides. The study revealed that majority of the respondents aged between $41-53$ years (56.43\%), studied upto High School (46.07\%) and had membership of at least one organization (70.72\%). Most of the farmers had family size of 5-7 members $(62.50 \%)$, agricultural experience between 16-23 years (62.85\%) and in between 4-9.6 years involved in pesticide application $(60.71 \%)$. The knowledge regarding various IPM practices plays a vital role in its application. The study found that more than half (52.85\%) of the paddy growers had moderate level of knowledge on IPM practices next to which 27.85 per cent of the farmers had low level of knowledge and 19.28 per cent of them had high level of knowledge regarding IPM practices. The farmers had great extent of knowledge on the practices like proper summer ploughing, trimming of bunds and destruction of crop residues before transplanting of rice to minimize the insect pest and disease intensity as reported by all the respondents and use bird perches for predatory birds against insect pests of rice was reported by 90.00 per cent of the respondents. However, majority (69.28\%) of the respondents did not know about application of Trichogramma as a biocontrol agent against rice stem borer, rice leaf folder and more than three forth of the respondents (76.78\%) did not know about pattern of release of Trichogramma in the field. It shows that farmers had very low knowledge in application of biological pest control techniques in the field coparing to cultural practices.

How to cite this article : Sharma, P. and Mishra, P. (2020). Paddy growers' technical knowledge on integrated pest management practices in Upper Brahmaputra Valley Zone of Assam. Agric. Update, 15(3): 215-220; DOI : 10.15740/HAS/AU/15.3/215-220. Copyright@2020: Hind Agri-Horticultural Society. 